\title{
EMBRACE, EMBED AND ENLIVEN: AdVANCING SOCIAL RESPONSIBILITIES AT THE UNIVERSITY OF NORTHAMPTON, ENGLAND
}

\author{
Emel Thomas ${ }^{\mathrm{a}}$ \\ Wray Irwin \\ University of Northampton
}

\begin{abstract}
As the United Kingdom's (UK) first Ashoka U Changemaker Campus, the University of Northampton (UoN) has embarked on a strategy that embraces social enterprises. Social enterprise, innovation and entrepreneurship are key competences that have been used by the university to address social inequalities. This paper will account for the social engagement challenges that are influential in the UK's higher educational environment. International perspectives will be highlighted to demonstrate that significant advantages can be obtained by borrowing and adapting policies and practice strategies. Our primary aims are: to showcase the fundamental activities of social responsibility as demonstrated by UoN and provide examples of stakeholder demands during periods of significant change. We argue that it is essential for higher education institutions (HEI) to develop a more nuanced and innovative examination of community based initiatives and networks in order to sustain engagement and access.
\end{abstract}

Keywords: Ashoka, changemaker, community based initiatives, engagement, social enterprise, social innovation, social responsibility

\section{Introduction}

Finance from public funds to English universities is administered through the Higher Education Funding Council for England (HEFCE). Of these funds, close to $4 \%$ is dedicated to an innovation fund that seeks to demonstrate commercial application (Williams, 2015). Therefore UK universities engage in a range of activities beyond education and research. Some create legitimate connections within the public and private sectors. This can result in a conflict between the private sectors' mission for a profit and the public's need for evidence of social good. In recent decades, there have been major changes in higher education (HE). One such change is the development of opportunities for social mobility. Indeed obtaining a HE qualification is seen as a pre-requisite for economic growth and competitiveness. HE has become an industry that 'enhances national competitiveness... a lucrative service that can be sold in a global market place... [eclipsing] the social and cultural objectives' (Naidoo 2003, p.250). The commodification of HE has created some tensions between the economic role of a university and its social responsibility to the communities it serves.

After the 2009 financial crisis, HEl in England grappled with creating and sustaining 'impact' for their diverse communities. Universities sought to ensure a positive strategic ethos whilst developing intellectual capacity for all stakeholders and mediating global league tables and university rankings. The University of Northampton (UoN) is no exception to these demands and responded by carving out an active space for the role of social enterprises, entrepreneurship and innovation. This paper attempts to explore the development of this strategy over one strategic planning cycle, from 2011 to 2015 , in the context of social responsibility. It presents an overview of the innovative activities

\footnotetext{
Correspondence can be directed to: emel.thomas@northampton.ac.uk
} 
undertaken by the UoN in recent years to further its social impact and identify the barriers to success. This paper is based on a stakeholder consultation programme undertaken in 2013 which focused on what a Changemaker Campus, as a proxy for a socially innovative university, meant to staff, students and communities. This paper presents a model for a socially responsible HEl in the English context.

\section{Demands for Inclusion within Higher Education}

$\mathrm{HE}$ in England is a state governed system with the HEFCE granted responsibility for funding and regulation from 1992. Government grants given for teaching allocations in HE were withdrawn in 2012 and resulted in universities needing to cover income previously received from HEFCE. As a result most universities charge UK and EU undergraduate students tuition fees (up to $£ 9000$ British Pounds a year). There are 108 universities in England of which some have evolved as a result of legislation that allowed smaller colleges to obtain university status. Since the financial crisis of 2009, the UK's policy of austerity led to a redefining of the role of local government and state agencies in addressing social inequalities. The role of $\mathrm{HEI}$ has been reassessed to incorporate explicitly positive social, environmental and cultural impacts alongside their economic contribution (Altbach et al., 2009). Of interest is how university resources can be used to support state provision, deeper local commitments and demonstrate positive community action. In response many $\mathrm{HEI}$ developed strategies whereby the community could actively get involved in student experiences, taught curriculum, and research projects. The purpose for change in $\mathrm{HE}$ is often debated, especially when considering the divergence between education perceived as a tool for social/economic transformation and education for wider social justice/responsibility ideals. Cristensen and Eyring (2011) argues that moving from an 800-yearold model of universities as economic agents driven by education, research and knowledge creation would enable them to become more innovative and sustainable in the crowded global HE market place. By focusing their energies and resources on generating social impact and justice, as ways of enhancing learning in the community, universities would become disruptive innovators within society producing economic and social benefits.

During the early 2000s in England, the Labour government overtly sought to support HEl that engaged with communities and widened participation. In 2003 the Education Secretary proposed extra funding for universities that attracted students from disadvantaged backgrounds. However in the years following the financial crisis, the need for austerity meant a greater emphasis on financial allocations that promoted capacity building. Specifically this could be evidence by using 'impact' measures as an indication of value added and engagement (Brennan, 2008; Grimshaw and Rubery, 2012). Social engagement and demands for greater social inclusion in HE therefore stretched beyond the traditional priority of increasing the numbers of underrepresented students within $\mathrm{HEI}$ to objectives that involved universities developing interventions. It was deemed important that these interventions addressed the root causes of inequality and the lack of engagement in HE in a systemic way. This approach has created new ways of widening participation in HE; something that not only satisfies the economic role of HEls but also leads to the tackling of global social inequalities. In this model the centrality of widening participation in $\mathrm{HE}$ rather than it being treated as a by-product of $\mathrm{HE}$, a means to an end rather than an end in itself, creates the disruption through which different ways of viewing a university's social impact are emerging.

\section{Engagement Responsibilities}

There exist two broad challenges for HEI when addressing social engagement demands in local communities. First, engagement must be seen to provide encounters that are cost effective and workable for the target group(s). For universities this is an essential element when seeking to establish and maintain widening participation opportunities. Second, ensuring a quality of service for communities, students, and the university is critical. Particularly if seeking to achieve durable 
and principled service activities. These two challenges create a tension; as quality-based activities may not always be the most cost effective ones, and the cheapest form of intervention may not result in the greatest impact. Without regular reflection and renewal of engagement activities, the aim of addressing contemporary social justice and responsibility agendas can quickly disappear (Curtis, 2010). In crisis situations, such as the financial crash, there are often benevolent services established that fulfil social needs (often neglected due to government cut backs on public services) which do not address the systemic issues that cause the social problem in the first place (Newing, 2011). In attempting to respond to economic pressures, social engagement demands require a local compassionate response by more powerful agents such as universities and their community based initiatives, rather than quick fixes that respond to political expediency rather than long term change (Chatterton, 2000). For example, following the closure of government funded youth clubs within the East Midlands region of England, small teams of individuals established local groups to support young people by offering services to meet their needs through a Youth café model (Sorrel Youth Cafe, 2016). Such initiatives when supported in an empathetic way by an HEI can create new pathways into university for disadvantaged young people, whilst providing a conduit through which an $\mathrm{HEI}$ can focus its resources for the benefit of that community. It is in this situation the creative ideals of community engagement undertaken by an $\mathrm{HEI}$ can be most effective when harnessed through a social enterprise business model.

In recent decades social enterprises in the UK have grown in number (BIS, 2013). Social enterprise business models provide an operating framework through which social entrepreneurs, communities and other stakeholders create innovative solutions to actual problems. When considering international conceptions of social enterprises Kerlin (2010, p.164) states they are:

...the use of nongovernmental, market-based approaches to address social issues, social enterprise often provides a "business" source of revenue for many types of socially oriented organizations and activities. In many cases, this revenue contributes to the self-sufficiency and long term sustainability of organizations involved in charitable activities... Indeed, as the concept has grown in popularity, the actors and institutions involved in the promotion and development of social enterprise appear to reflect its immediate regional socioeconomic environment in terms of social enterprise emphasis, structure, and resources.

Consequently, social enterprises are increasingly being explored as an avenue for HEls to exert social responsibility within wider society. In considering international definitions of social enterprise it is important to recognise that the context is crucial when attempting to understand the localities in which these organisations are established and operate in (Kerlin, 2006). Alongside contextual issues, commercial understandings of social enterprise differ in part to societal, legal and regulatory frameworks and political conceptions. According to Austin et. al (2006, p.2) there is a need to look beyond social-purpose versus commercial ventures and create something '...new rather than simply the replication of existing enterprises or practices'. Hence the most efficient and effective route of addressing social issues is within the process of continuously making socially responsible decisions. On the other hand the UK government, in part, suggests that social and environmental aims are not the sole identification of a social enterprise, proposing five income and profit indicators that can ratify the status of a social enterprise (BIS, 2013). In recent years the UK's expertise in the social enterprise field has been embraced as a form of soft power; promoted through British Council initiatives across the world, shaping the debate and application of social enterprise within HE along an Anglo-centric model of engagement. In some instances creativity and diversity within the field could be limited when opportunities are not fully embraced. Therefore, the contextual differences through which social enterprises emerge within different countries are important considerations in order to develop new models that address social problems (Peattie and Morley, 2008). 


\section{International Perspectives: Borrowing Policy and Practice}

Emulating successful policy and practice from elsewhere has long been viewed as a way in which institutions can learn and develop. However transferring ideas and practices across national boundaries is often highly complex. According to Phillips and Schweisfurth (2006) the foreign example needs to be fully understood and reflected on in context prior to adoption. As such policy transfer associated with $\mathrm{HE}$ has a well-established history linked to performance strategies. For example performance-based accountability models from the USA have been adopted by countries in transition across Asia and Eastern Europe (McLendon et al., 2006). Smaller countries such as those within the Commonwealth Caribbean or Netherlands Antilles are particularly vulnerable to the transfer of external policies and practices. Although criticisms of policy and practice borrowing regularly focus on dependency on former colonial powers, however in recent times two primary benefits are evident. The first is that particular relationships with partners can help to cluster similar interests and strengths. This can result in a strong network of contacts that can be called upon at a moment's notice (frequently using a range of technologies). The second is mutual benefits from financial resources and status. For example through affiliations with English institutions 'prosperity' and 'success' are associations that can reassure stakeholders (Thomas and Clegg, 2016). Indeed for the development of social enterprises, partnerships and recognition are key drivers in the global environment.

\section{The Merits of Social Enterprise for Higher Education Institutions}

It is estimated that $24 \%$ of small and medium sized enterprises in the UK are social enterprises (BIS, 2013). Although HEls may collaborate with others on matters associated with entrepreneurship it is somewhat unclear as to how many social enterprises are set up and remain operating in the wider $\mathrm{HE}$ sector. Emerging, however, are rich narratives showcasing the benefits for HEls in creating and supporting social enterprises and entrepreneurs (Drayton, 2006). There are four primary benefits for HEl that exert social responsibilities through creating and/or sustaining social enterprises (Denny et al., 2011; Irwin and Maxwell, 2015).

1. The creation of relationships with diverse communities. For example working with local schools, beyond teacher training programmes, to establish social enterprises and events can create links with parents, teachers, teaching assistants, children and local authorities.

2. Co-ventures that contribute to knowledge creation processes. HEI can utilise social enterprise operations as sites in which to conduct research. Indeed the variety in function of social enterprises is likely to encompass a range of academic disciplines for research examination.

3. The ability to develop a HEI that is strategically engaged in socially responsible activities. Universities can operate more in line with organisational market ideals. For example the marketisation of $\mathrm{HE}$ in the UK has presented the arguments that universities need to address student demands beyond consumerism standards. However, with the inclusion of social enterprises in the activities of $\mathrm{HEl}$, strategic development can be inclusive of more commendable charitable objectives.

4. HEls can contribute to networks of likeminded entrepreneurs creating positive change regionally, nationally and internationally. The standout merit of this for both $\mathrm{HEl}$ and social enterprises is being involved in a large association of innovative partners. For example Ashoka was established first in India in 1980, Brazil in 1996, and the USA in 2000 making it now the largest network of social entrepreneurs.

Ashoka is one of many networks that operate nationally (Guardian Social Enterprise network), within Europe (EMES International research network) and globally (Schwab Foundation, Global Social Enterprise network). Exponents of the 'Everyone a Changemaker' ideal Ashoka seek to: 
...exponentially accelerate lasting social change so it sweeps through systems, tipping the attitudes and behaviour of individuals and institutions. It convenes and connects highpotential changemakers, their ideas and their resources, through the power of collaborative competitions and partner networks (Ashoka, 2016, para 1).

Ashoka's unique approach is in its focus on recognising the power of the social entrepreneur and innovator who changes the world through social innovation and has developed a 'search and selection' processes that 'remains the most rigorous system... for identifying pattern-setting innovators at a relatively early stage of their careers' (Bornstein 2007, p. 12). It is this process that provides credence to the 'lone warrior' narrative of social enterprise, but fails to acknowledge that many social enterprises and innovations require teams, communities, champions, and luck. Networks like this could perpetuate the idea that the only successful social entrepreneurs are the ones that succeed with their venture. It fails to acknowledge that many social innovations are the result of the collapse of others and fails to recognise their contribution. Out of these concerns and a newly desired approach, in 2008, Ashoka U emerged as a sub-venture within the Ashoka network. Ashoka $U$ took the idea of the driven change-making social entrepreneur and applied that to universities, arguing for an institutional change approach that could influence students and enable collaboration with colleges and universities. It was anticipated that such collaborations would break down social barriers and lead to university campus-wide movement of social innovation. Ashoka $U$ universities therefore are often identified as unique ecosystems in society where social change can be generated through engagement with social innovation and creating Changemakers of the future that will change the world for the better.

There are 35 Ashoka $U$ Changemaker campuses around the world that foster skills such as empathy, teamwork, leadership and change making across their institutions and curriculum activities. Although involvement in a large international network runs the risk of not fully discerning local innovative drivers, enterprising associations such as Ashoka $U$ are able to showcase powerful narratives of the impact HEls have when adopting socially responsible strategies (Drayton, 2006; Sen, 2007). No work has been undertaken to review the impact of Ashoka $U$ and its network in effecting the desired systemic change. It is too early and has to date been restricted to a North American narrative of social enterprise and innovation with a language that is rooted in a liberal arts educational system. However its application of the Ashoka search and select process provides validation of those universities that have embedded social innovation and built supportive environments for change making. How real such claims are, and whether an institution can be judged the same way as an individual in this context is still to be tested.

The UoN is one the youngest universities within the UK. Located in the East Midlands of England, the UoN is currently split across two sites in the county town of Northampton. The university has plans to amalgamate into a new Waterside Campus along the River Nene in 2018. The educational history of Northampton dates back to the thirteenth century. However it is only in recent decades that a $\mathrm{HEl}$ in Northampton has formally acquired university status. The UoN is therefore vocal in its desire to support creativity and create strategic partnerships. For the UoN the four primary merits of involvement with social enterprises are not considered to be exclusive. The overarching priorities of improving inclusion and engagement required different approaches much dependent upon the locality. It is within this context that the UoN embarked on embracing social enterprise, entrepreneurship, and innovation as a strategic core competence and sought to become the UK's first Ashoka U Changemaker Campus.

\section{Social Responsibility: Embracing Enterprise and Innovation}

Granted University status in 2005 , the UoN comprised six academic schools; Health, Education, Social Science, Business, Arts, and Science and Technology. As a post-1992 HEl, the UoN's responsibilities to local communities was a central tenent of its application for university status, which was heavily 
supported by those communities. The student body of 13,000 students reflects its context with $61 \%$ of students who are the first in their family to attend university; $60 \%$ mature students; $25 \%$ Black and Minority Ethnic; $10 \%$ declaring a disability; and $12 \%$ of international students representing the student body. The course portfolio at the University offers a range of professional programmes connected to education and health professions alongside standard business programmes, performance arts and high end technology based programmes. Viewed as a practical rather than academic university, graduates of UoN have consistently reported high levels of employability (currently at $96 \%$ employed) (HESA, 2017).

With the Mission of Transforming Lives and Inspiring Change, the University's strategic plan of 2010, Raising the Bar, (UoN 2010, pp.3-4) spelt out that:

Social Enterprise is [a] uniting theme across the six Schools that builds on strengths in community interaction, regional engagement, widening participation, third sector partnership, student volunteering and employability... National recognition of Social Enterprise as a holistic theme will confer an important point of external differentiation on the University.

The 2010 plan identified that social enterprise was a cross-cutting theme that built on the existing strength of the University offering a differentiator for the institution. Whilst it is acknowledged that the policy, political, and economic context of the UK played an important role informing the strategy, this section will explore the antecedence of this strategy. Also showcased are the different interpretations social enterprise adopted and resultant activities undertaken to achieve this ambition by being awarded the first Ashoka U Changemaker Campus designation in the UK.

\section{The Early Years: Pre-Raising the Bar and 2010-2012}

Subject areas at the UoN worked closely with community groups and organisations through research, placement, and knowledge transfer activities. Co-operative models of working and trading were promoted in the 1990s, particularly in the Arts. In the Business School there was a cadre of academics who recognised that social enterprise was a developing field. Across the School of Health, colleagues grappled with the concept following the White Paper of 2006, later the Health and Social Care Act, which looked to a growing social enterprise sector to deliver health outcomes (Department of Health, 2006). Whilst there was real grass-roots engagement, interest and activities were peripheral to the mainstream activities of the University and involved a band of enthusiasts. The adoption of 'Raising the Bar' legitimised the interest in social enterprise and gave permission for activities to be developed in the name of achieving the strategic plan (UoN, 2010).

Although the intent was constructed, there were many issues to resolve from the outset. This included definitional problems around the concept of social enterprise. What was meant by National 'recognition', and how the university would engage students in a concept that as discussed previously in this paper, is contested and multi-definitional and for the University, resulted in an array of discussions. As there was (and remains) no legal definition of social enterprise, the UK government's definition was adopted:

A social enterprise is a business...with primarily social objectives whose surpluses are principally reinvested for that purpose in the business or community, rather than being driven by the need to maximise profit for shareholders and owners (Cabinet Office 2006, p.10).

The focus was consequently on activities that enhanced student experience, addressed social inclusion, social impact, social innovation and change; and were entrepreneurial, innovative and utilised enterprise skills. These parameters provided the template for staff and student engagement and provided a clear narrative through which to engage external stakeholders.

Throughout its infancy there were three key drivers. First, an enhanced student offer where all students could experience a social enterprise or be supported to start one. Second, a social 
enterprise integrated into curriculum in the form of placements, assignments, and assessments.

Finally, access to business support to start and grow social enterprises.

At the UoN specific initiatives were introduced. Six prominent examples include:

(a) Social Enterprise Development Fund, where training, advice, mentoring and start up grants of between $£ 3,000$ and $£ 20,000$ for students and staff were made available;

(b) Inspire Northamptonshire, a voluntary sector partnership building capacity in the sector, offered leadership training and collaborative service delivery guidance;

(c) New Venture Development, WE RE PC (a recycling business that folded in 2012) and Coco Careers (a graduate recruitment agency operating as a social enterprise);

(d) Inspire2Enterprise, provided a 'one stop-shop' business support service for social enterprises. Online, telephone and face-to-face assistance became available in this platform to new and existing social enterprises that supported over 7000 organisations between its launch and 2015;

(e) Direct investments in high growth social enterprises, such as Goodwill Solutions; a social enterprise logistics firm supporting ex-offenders into work;

(f) The externalisation of university functions into social enterprises, with the Estates and Catering departments being assigned as social enterprises with more autonomy around budgeting and service delivery.

The period 2010-2012 can indeed be identified as a period of ambiguity and unfocussed activity brought about by lack of agreement on concepts and terminology, which in turn stimulated a number of discourses within the UoN. The prevailing narrative concentrated on the Cabinet Office's (2006) definition and 'Business' support, that in some regard inhibited staff and students outside of the Business School from getting involved. As one student in the School of Education pointed out:

I want to be a teacher not start a business (Anonymous - Student Narrative, 2011).

This perception that social enterprise was exclusive rather than inclusive created additional difficulties for external stakeholders. The UoN's objectives and approach were heavily questioned and was seen as disruptive and unaccountable without any clear social benefit. The over emphasis of a 'business' definition narrowed the engagement opportunities and raised questions about whether initiatives were being developed in a strategic way or represented ad hoc land grabs and cost reduction priorities for public relations purposes. Hence there emerged an interest in what was becoming a focus on 'Social Innovation' (Denny, 2011).

\section{The Mid-Years: 2012-14}

Social innovation emerged through the UoN partnership with the Young Foundation, establishing the first Social Entrepreneur in Residence (SEiR) in a UK HEI. Like social enterprise the field of social innovation is contested and emergent. The Open Book of Social Innovation defined social innovation as:

...new ideas (products, services and models) that simultaneously meet social needs and create new social relationships or collaborations. In other words, they are innovations that are both good for society and enhance society's capacity to act (Murray et al. 2010, p.3).

This meant that the focus shifted away from creating new social enterprises to the generation of ideas in order to address inequalities and the process of developing and disseminating these across whatever sector or business model was appropriate. Understanding social problems, evidencing needs, learning from failure, measuring social impact as the way of unlocking investment and 
contracts, prototyping and design thinking all became part of the new narrative at the UoN. 'Just have a go' became the way students were encouraged to 'get involved'. Emergent initiatives at this time included:

(a) The Big Ideas Bonanza that supported 160 community and social ventures with investment up to $f 30,000$ during this period;

(b) We Do Ideas Northampton Harnessing App technology created new spaces where students could share and develop their ideas into viable, income generating social ventures. The approach brought in academics and students from a wider range of disciplines than had previously been seen;

(c) Social Innovation Curriculum, where academics began to broaden their curriculum to incorporate a social innovation approach. The Bachelor of Arts (BA) Business and Enterprise redesigned its modules to accommodate approaches to venture development and the BA Acting degree introduced a Social Enterprise in an acting module where social innovation underpinned the learning;

(d) Social Enterprise Ambassadors, where 200 individuals were recruited to build a community of innovators practicing and engaging students in thinking about social problems and how they would solve them;

(e) Global opportunities such as the Dialogue Cafe and Balloon Ventures broadened the appeal of the UoN agenda and offered new kinds of enhancements to the student experience that connected students with global communities and innovators.

UoN's original approach of the early years continued to develop with its focus on social enterprise models, even though there was a growing awareness of the process of social innovation as a mechanism for creating new social enterprises. These two strands developed in parallel; informing and influencing each other but cultivating very different roles in the development of the UoN strategy. The benefits of this approach allowed for a richer dialogue to develop with external stakeholders and opened up new opportunities for closer working. However there remained no clear objective for social change other than the mission to be the 'Number 1 for Social Enterprise'.

Social innovation was predominantly internally driven focussing on curriculum enhancement, student engagement and extra-curricular activities whereby addressing social problems through subject-specific knowledge rather than business creation was seen as the priority. As these mid-years progressed, the lack of an agreed definition that had dominated the social enterprise world for so long began to influence participants of social innovation. Indeed the emergent definitions, theoretical framings and conceptual theories correlated with those in the University whereby social innovation began to mean different things to different individuals. The impact of much activity on communities, students, and ways of working was also being questioned. There emerged the perception that the public relations objective of being first could be overshadowing real social impact.

\section{Changemaker Campus}

The UoN came to the attention of Ashoka U in 2012. After undertaking the 'search and selection' process the UoN was awarded Changemaker Campus status in February 2013. The designation recognised how both strands, internal and external, were enhancing each other, providing choice, challenge, and an integrated approach to growing the fields of social enterprise and social innovation. What initially appeared as a tension in the University between the two approaches was taken as a strength and more than that as best practice within the Changemaker Campus network. However the process identified the lack of embedded strategic intent beyond the objective of being 'Number 1 for social enterprise'. The need to embed social innovation as a competency that impacted on all stakeholders was needed and that this would require systemic changes to networks and relationships both internal and external. 
Whilst the strategic objective could be said to be achieved, the real work would need to be undertaken to create the systemic change required to have sustainable social impact. Beyond the status of Ashoka $U$ being awarded, little thought had been given to what would happen next or what being a member of the Ashoka network would mean in practice, especially if the university was to lose such attention in the future.

\section{Towards a Changemaker University: Embedding Debates}

Prior to the UoN designation, all Changemaker campuses had been located in North America. This gave rise to debates on how the language of Changemaker could be translated into a UK context. Indeed wider examples of policy and practice transfer would suggest that a different HE context could lead to Changemaker being defined differently and so to notions of social innovation (Kerlin, 2010). The Ashoka $U$ definition of a Changemaker Campus suggested that all designated campuses should achieve embedded social innovation as a core value. However, what did embeddedness mean in the English context and how was the UoN able to demonstrate this commitment? Fundamentally, what did Changemaker, as a proxy for social innovation, mean in Northampton? In order to understand these issues a staff consultation was undertaken over a period of six months utilising survey, focus groups, and workshops, which was extended into the student body and external stakeholders. The questions asked focussed on what the term embedded social innovation meant in relation to Northampton, and how the Changemaker ethos added value to the UoN's pre-existing values and mission.

\section{The Consultation and Data Collection}

To explore the social innovation as an embedded concept an online survey was cascaded through the UoN in-house communication mechanisms, all staff emails and the in-house magazine. Five staff meetings were conducted where Changemaker was explored in depth. Seven community workshops were undertaken as informal focus groups where 57 community and voluntary sector organisations attended. Collectively over 500 responses were received across staff and community organisations from September 2013 to February 2014. The analysis of the responses was initiated using a primary level evaluation. Discussion points were validated by a selection of those involved in the consultation as well as the UoN Executive and Trustee Boards. The validation process both confirmed the findings and raised questions for further exploration outside of the scope of this paper. However the findings draw on the importance of local duties in a dynamic HE environment. Elements of the findings are drawn upon in the following discussion sections as a means of promoting flexible systems for navigating the concepts of social enterprise and social innovation.

\section{Embeddedness}

Granovetter (1985, p.504) argues that 'most behaviour is closely embedded in networks of interpersonal relations...' and that he '...believe[s] this to be so for all behaviour'. Furthermore he asserts that by analysing such embedded behaviour as 'rational' within the context of the institution 'what looks to the analyst like non-rational behaviour may be quite sensible when situational constraints, especially those of embeddedness, are fully appreciated' (Granovetter 1985, p.506). For the UoN grappling with the networks of relations value could only be achieved through innovative research. Indeed this could enable the revelation of behaviours that occur beyond what is scripted strategically. Purposive action could also be embedded in an on-going system of relations. What also was needed is deep consideration of opposing ideals associated with embeddedness. According to Karl Polanyi (Machado 2011, p.1) the idea of [dis] embeddedness occurs when '...the economy is immersed in social relations, i.e., it cannot be a separate, autonomous sphere vis-a-vis society 
as a whole'. However a dis-embedded economy's main function was not to provide the means by which society could live and thrive but to generate profit for and of itself with no relationship to the real economy in which people live. Applying such notions to social innovation within an $\mathrm{HEl}$ raised questions about the role and function of social responsibility and innovation within the UoN as an organisation. To be embedded social innovation would need to be recognised as a rational behaviour set that added value to the interrelationships, discourse, and institutional development of the UoN both at macro and micro level, rather than a narrative for marketing and promotional purposes. To analyse the data, Daszko and Sheinberg's (2005) types of change framework was adopted to plot responses in terms of their correlation to transformational change pre-requisites.

\section{Findings and Dialogues}

One principal concern from the consultation findings was that respondents acknowledged and demonstrated commitment to the UoN mission, but felt they had little influence over the decisions the University took in achieving this mission. Some respondents highlighted that decisions appeared to be made through a process they termed bureaucratic that they did not participate in. It was felt that such processes would ultimately hinder the opportunities Changemaker offered staff to 'do things differently' as the bureaucracy would control what emerged. Changemaker and its ethos of 'Everyone a Changemaker' was seen to imply that every member of staff was empowered and responsible for effecting change in order to improve outcomes. However, the perception that the UoN governance was 'exclusive' and bureaucratic rather than people-led and student-centred was counter intuitive to such an ethos (Curtis, 2010). Viewed as such, Changemaker was for some seen as:

...just another initiative or badge that would have little impact on the day to day experiences of staff or students' (Anonymous - Workshop Participant, 2014).

For others, the potential for Changemaker in providing a new way of embodying the UoN mission was seen as a positive opportunity. 'Everyone a Changemaker' was therefore viewed as the lens through which the UoN could make its values real, rather than an additional layer of values. It also provided clear objectives and set actors that were involved more in the systems at the university. This was taken to be viewed as a way to enliven the relationships between all stakeholders and partners. One example highlighted was the potential for the relationship between academics, students, professional services and wider community to become one of co-creation and co-production: these in turn generating new models of staff engagement, curriculum development, and/or greater adaptability and flexibility.

Changemaker was also perceived as a way of regulating institutional relationships: bridging the gaps between internal and external communities in the context of Northampton, affecting change rather than outright disaffection with the status quo. Whilst at that time some relationships at the UoN were seen as governed and regulated through strategies, policy, and procedure, Changemaker was seen as an alternative approach which could develop trust, leadership, responsibility, transformation and the courage to fail. Although tensions were identified between four communities of interest: environment (including external stakeholders and communities), staff experience, student experience, and leadership, it was acknowledged that these were inter-related constituencies and expressed as interdependent with changes needed across all four if Changemaker was to be seen as embedded. Each constituency saw Changemaker as something that related to other people not them. For example, academic staff stated:

Changemaker... it's about the student experience and communities isn't it? It's not about what we do? (Anonymous - Staff Narrative, 2014). 
Whilst professional services saw it as:

...nothing to do with us it's about how academics deliver to students (Anonymous - Student Narrative, 2014).

The sense of Changemaker belonging to others and not self-actualised reinforced the view that it was a 'bolt on', not part of business as usual or embedded into ways of university working. This was further amplified by the view that the prevailing mind-set was bureaucratic rather than creative or innovative. Respondents commented that it was this very bureaucratic mind-set that was inhibiting creativity and innovation and would ultimately stop Changemaker making a difference. Where examples of creativity and innovation were identified, they were expressed as being 'in spite' of the University, rather than 'facilitated by the University' and not seen as being universally celebrated. Whilst neither one of these mind-set 'frequencies' should be seen as more desirable than the other, Changemaker was seen as being less a part of a bureaucratic ecosystem and potentially a transformational development.

In utilising Daszko and Sheinberg's (2005) framework, it is possible to lay bare the shifting ideals of embrace, embed and enliven notions of social responsibility linked to the implications of being a Changemaker Campus at the UoN.

Table1. Embrace, Embed and Enliven Analysis for the University of Northampton

\begin{tabular}{|c|c|c|c|}
\hline & $\begin{array}{l}\text { Embrace } \\
\text { Where the University is? }\end{array}$ & $\begin{array}{l}\text { Embed } \\
\text { Current application of } \\
\text { University values. }\end{array}$ & $\begin{array}{l}\text { Enliven } \\
\text { What a Changemaker campus } \\
\text { could be? }\end{array}$ \\
\hline $\begin{array}{l}\text { Motivation for } \\
\text { change }\end{array}$ & Better, faster, cheaper. & Fix the problem. & $\begin{array}{l}\text { Survival, environment, world } \\
\text { changes, society, break through } \\
\text { needed. }\end{array}$ \\
\hline Degree of change & $\begin{array}{l}\text { Incremental } \\
\text { improvements. }\end{array}$ & $\begin{array}{l}\text { Transition from here } \\
\text { to the future. }\end{array}$ & Revolutionary, necessary. \\
\hline Thinking & Improve & $\begin{array}{l}\text { Change management, } \\
\text { strategic planning. }\end{array}$ & $\begin{array}{l}\text { Radical shift in mind-set/ } \\
\text { thinking/actions. }\end{array}$ \\
\hline Actions & $\begin{array}{l}\text { Manage and control } \\
\text { processes. }\end{array}$ & $\begin{array}{l}\text { Design the plan, } \\
\text { deliver the plan. }\end{array}$ & $\begin{array}{l}\text { Root and branch overhaul } \\
\text { of mind-set, culture, } \\
\text { communications, strategy, } \\
\text { structure, actions, systems and } \\
\text { processes, use of data, action } \\
\text { focussed, research driven and } \\
\text { evaluated. }\end{array}$ \\
\hline Destination & $\begin{array}{l}\text { Improvements are } \\
\text { limited to addressing } \\
\text { things that go wrong. }\end{array}$ & Projects completed. & $\begin{array}{l}\text { Continually transforming: no } \\
\text { end state. }\end{array}$ \\
\hline Changes required & $\begin{array}{l}\text { Focus on individual } \\
\text { performance, PDRs, } \\
\text { improvement in } \\
\text { skills, knowledge, and } \\
\text { performance. }\end{array}$ & $\begin{array}{l}\text { Control, project } \\
\text { management. }\end{array}$ & $\begin{array}{l}\text { Leadership committed to new } \\
\text { thinking, learning and actions, } \\
\text { external coaching to help see } \\
\text { the challenge, courage. }\end{array}$ \\
\hline Outcomes & Limited improvements & $\begin{array}{l}\text { Changes limited to } \\
\text { project plans }\end{array}$ & $\begin{array}{l}\text { Sustainable change, adaptability, } \\
\text { fluidity, state of constant } \\
\text { change, team approach. }\end{array}$ \\
\hline
\end{tabular}

Source: Daszko and Sheinberg $(2005$, p.3) 
The biggest implications were that whilst the Ashoka designation process identified a level of embeddedness of social innovation into the UoN that in part falls short of a Polanyi or Granovetter definition (Granovetter, 1985; Machado, 2011), neither the institution nor the social processes as identified in the Cajaiba-Santana (2014, p.48) framework had changed and that was partly because prior to the designation neither of the narratives adopted by the UoN had led to a sense of agency across the staff body. Changemaker, and in its name social enterprise and social innovation, appeared for some to be happening somewhere else and not relevant to the majority of staff. Up until February 2014, the end of the consultation period, a systemic change perspective of social innovation had been missing from the discourse of social innovation at the UoN with the emphasis being on venture development and co-development perspectives.

\section{An Enlivened Future for the University of Northampton}

The outcome of the consultation implies that for a Changemaker Campus to demonstrate reputable social innovation the three stages; embrace, embed and enliven should be identifiable. Furthermore, an evaluation of the wider structural and institutional context of social innovation needs to be undertaken to demonstrate how agency, social practices and new norms and behaviours emerge and affect social change. The Changemaker designation provided the UoN with the ability to claim the 'Number 1 for social enterprise' title. Yet the institution needed to move beyond the status to create a system that would enliven relationships across all stakeholders if significant inclusion and engagement benefits were to be achieved. Social impact and social responsibility would need to remain key drivers for future development.

\section{Conclusion}

Globally HE is complex and an increasingly competitive market place. In the UK, the government has encouraged HEls to establish evidence of social responsibility, which could be validated in the operations of social entrepreneurship. It is also apparent that there are engagement demands for widening participation from not only the government but communities themselves. Compassionate concern for societal issues can result in a flurry of social enterprising activities much of which offer swift responses to challenges caused by short term political decisions with no long term social impact. Borrowing policy and practice has long been viewed in literature as challenging without contextual consideration, investment and partnership. However, the UoN has adopted a deliberate strategy of social impact through innovations as the way of reconciling the social responsibilities in England. Whilst the UoN has captured this under their Changemaker Campus initiative, all universities should seek to embed socially responsible activities. What is clear is that the demands of the future require new thinking and ways of working if HEls in England are to optimise their social role. This will require them to embrace these new demands, embed an ethos that will affect the change and enliven their institutions to be transformational agents within their communities.

\section{References}

Altbach, P.G., Reisberg, L. and Rumbley, L. E. (2009). Trends in Global Higher Education: Tracking an Academic Revolution. Report prepared for the UNESO World Conference on Higher Education. Paris: UNESCO. Available at http://unesdoc.unesco.org/images/0018/001831/183168e.pdf. [Accessed 14 February 2016].

Ashoka (2016). Ashoka Innovators for the Public: Changemakers. Available at https://www.ashoka. org/changemakers [Accessed 28 February 2016].

Austin, J., Stevenson, H. and Wei-Skillern, J. (2006). Social and commercial entrepreneurship: Same, different or both? Entrepreneurship Theory and Practice, 30(1), pp. 1-22. 
Bornstein, D. (2007). How to Change the World: Social entrepreneurs and the power of new ideas. New York: Oxford University Press.

Brennan, L. (2008). Higher education and social change. Higher Education, 56(3), pp. 381-393.

Cabinet Office (2006). Social Enterprise Action Plan: Scaling New Heights. Office of Third Sector. London: HMSO. Available at http://webarchive.nationalarchives.gov.uk/20070108124358/ http://cabinetoffice.gov.uk/third_sector/documents/social_enterprise/se_action_plan_\%20 2006.pdf. [Accessed 23 February 2016].

Cajaiba-Santana, G. (2014). Social innovation: Moving the field forward. A conceptual framework. Technology Forecasting and Social Change, 82(1), pp. 42-51.

Chatterton, P. (2000). The cultural role of universities in the community: Revisiting the universitycommunity debate. Environment and Planning A, 32(1), pp. 165-181.

Christensen, C. M. and Eyring, H. J. (2011). The Innovative University: Changing the DNA of higher education from the inside out. San Francisco: Jossey-Bass.

Curtis, T. (2010). The challenges and risks of innovation in social entrepreneurship. In R. Gunn and C. Durkin (Eds.), Social Entrepreneurship: A Skills Approach. Bristol: Policy Press, pp. 83-98.

Daszko, M. and Sheinberg, S. (2005). Survival is Optional: Only Leaders with New Knowledge Can Lead the Transformation. Available at http://www.mdaszko.com/theoryoftransformation final_to_short_article_apr05.pdf. [Accessed 4 February 2016].

Denny, S. (2011). A Socially Enterprising University - A New Model for Higher Education? The Guardian, June 13. Available at http://www.theguardian.com/social-enterprise-network/2011/jun/13/ social-enterprise-higher-education-northampton-university. [Accessed 9 February 2016].

Denny, S., Hazenberg, R., Irwin, W. and Seddon, F. A. (2011). Social enterprise: Evaluation of an enterprise skills programme. Social Enterprise Journal, 7(2), pp. 150-172.

Department for Business Innovation and Skills (BIS). (2013). Social Enterprise; Market Trends. BMG Report Small Business Survey 2012. London: HMSO. Available at https://www.gov.uk/ government/uploads/system/uploads/attachment_data/file/205291/Social_Enterprises_ Market_Trends_-_report_v1.pdf. [Accessed 25 February 2016].

Department of Health. (2006). Our Health, Our Care, Our Say: A New Direction for Community Services. London: HMSO. Available at https://www.gov.uk/government/uploads/system/ uploads/attachment_data/file/272238/6737.pdf. [Accessed 23 February 2016].

Drayton, B. (2006). Everyone a Changemaker: Social Entrepreneurship's Ultimate Goal. Arlington, VA: Ashoka Innovators for the Public. Available at https://www.ashoka.org/files/ innovations8.5x11FINAL_0.pdf. [Accessed 9 February 2016].

Granovetter, M. (1985). Economic action and social structure: The problem of embeddedness. American Journal of Sociology, 91(3), pp. 481-510.

Grimshaw, D. and Rubery, J. (2012). The end of UK's liberal collectivist social model? The implications of the coalition government's policy during the austerity crisis. Cambridge Journal of Economics, 36(1), pp. 105-126.

Higher Education Statistics Agency (HESA). (2017). Data and Analysis. Available at https://www.hesa. ac.uk/data-and-analysis/students/destinations. [Accessed 5 March 2017].

Irwin, W. and Maxwell, R. (2015). When changemaker and employability met education. Presentation at the 2015 Ashoka U Exchange, University of Maryland, 26-28 February.

Kerlin, J. A. (2006). Social enterprise in the United States and Europe: Understanding and learning from the differences. Voluntas: International Journal of Voluntary and Nonprofit Organizations, 17(3), pp. 247-263.

Kerlin, J. A. (2010). A comparative analysis of the Global emergence of social enterprise. Voluntas: International Journal of Voluntary and Nonprofit Organizations, 21(2), pp. 162-179.

McLendon, M. K., Hearn, J. C., and Deaton, R. (2006). Called to account: Analyzing the origins and spread of state performance-accountability policies for higher education. Educational Evaluation and Policy Analysis, 28(1), pp. 1-24. 
Machado, N. M. C. translated by João Paulo Moreira. (2011). Karl Polanyi and the New Economic Sociology: Notes on the Concept of (Dis)Embeddedness. RCCS Annual Review 3/2001(3). Available at http://www.ces.uc.pt/publicacoes/annualreview/ficheiros/003/3345_7.AR3_ Machado_en_10.11.pdf. [Accessed 9 February 2016].

Murray, R., Caulier-Grice, J. and Mulgan G. (2010). The Open Book of Social Innovation. UK: The Young Foundation. Available at https://www.nesta.org.uk/sites/default/files/the_open_book_ of_social_innovation.pdf. [Accessed 9 February 2016].

Naidoo, R. (2003). Repositioning higher education as a global commodity: Opportunities and challenges for future sociology of education work. British Journal of Sociology of Education, 24(2), pp. 249-259.

Newing, R. (2011). Social Enterprises: Filling the Gap Where Market Has Failed. Financial Times, November 2. Available at http://www.ft.com/cms/s/0/8744e0ba-d16c-11e0-89c000144feab49a.html\#axzz41SzgeVVa. [Accessed 11 January 2016].

Peattie, K. and Morley, A. (2008). Social Enterprises: Diversity and Dynamics, Contexts and Contributions. London: Social Enterprise Coalition. Available at http://orca.cf.ac.uk/30775/1/ SE\%20Monograph\%20Published.pdf. [Accessed 5 March 2017].

Phillips, D. and Schweisfurth, M. (2006). Comparative and International Education: An introduction to theory, method and practice. London: Continuum.

Sen, P. (2007). Ashoka's big idea: Transforming the world through social entrepreneurship. Futures, 39(5), pp. 534-553.

Sorrel Youth Café. (2016). Somewhere to be, SYC Home. Available at http://www.sycafe.org/. [Accessed 23 February 2016].

Thomas, E. and Clegg, P. (2016). Transformative agendas and educational demands in the British and Dutch overseas territories of the Caribbean. In T. D. Jules (Ed.), The Global Educational Policy Environment in the Fourth Industrial Revolution: Gated, Regulated and Governed. Bingley: Emerald Group Publishing Limited, pp. 243-266.

University of Northampton (UoN). (2010). Raising the Bar Strategic Plan 2010-2015. Available at http://blogs.northampton.ac.uk/institutionalstrategyblog/files/2011/02/StrategicPlan-2010-15.pdf. [Accessed 18 January 2016].

Williams, G. (2015). England: Higher Education. In C. Brock (Ed.), Education in the United Kingdom. London: Bloomsbury, pp. 83-105. 